BHUMI: Jurnal Agraria dan Pertanahan

Received: March 31, 2019; Reviewed: April 7, 2019; Accepted: April 24, 2019.

To cite this article: Widayati, A \& Suparjan 2019, 'Reaktualisasi perjuangan Nahdlatul Ulama dalam mewujudkan kedaulatan sumber daya agrarian. (Studi gerakan demokrasi radikal pada FNKSDA)', Bhumi, Jurnal Agraria dan Pertanahan, vol. 5, no. 1, hlm. 84-98.

DOI: http://dx.doi.org/10.31292/jb.v5i1.321

Copyright: @2019 Asri Widayati \& Suparjan. All articles published in Jurnal Bhumi are licensed under a Creative Commons Attribution-ShareAlike 4.o International license.

\title{
REAKTUALISASI PERJUANGAN NAHDLATUL ULAMA DALAM MEWUJUDKAN KEDAULATAN SUMBER DAYA AGRARIA (Studi Gerakan Demokrasi Radikal pada FNKSDA)
}

\section{THE REACTUALIZATIONOF NAHDLATUL ULAMA STRUGGLE IN REALIZINGTHE SOVEREIGNTYOFAGRARIANRESOURCES (Study of Radical Democracy Movement of FNKSDA)}

\author{
Asri Widayati dan Suparjan \\ Pembangunan Sosial dan Kesejahteraan, Universitas Gadjah Mada \\ Email: asri.widayati@mail.ugm.ac.id
}

\begin{abstract}
This research aim to explain the reactualization of Nahdlatul Ulama (NU) struggle over agrarian resources related to the emergence of Front Nahdliyyin for the Sovereignty of Natural Resources (FNKSDA) in 2013. This paper used the theoretical perspective of radical democracy movement proposed by Ernesto Laclau and Chantal Mouffe by analizing the phenomenon of NU struggle over agrarian resources. This research uses qualitative method by various specif ic case study with the type of single case study. The results revealed many cases of living space deprivation, inequality of natural resources ownership, and other agrarian conditions happened to nahdliyyin in several regions. The young members of NU which have been evolved by the time, did not merely criticize the government at the time, however, in a further way, they initiated the formation of movement in post-reformation era by radicalizing political space which should be more democratic. FNKSDA does not move structurally but it moves inside of NU culturally. Nevertheless, the 'new political and cultural identity' represent the progressive characteristic of NU.
\end{abstract}

Keywords: FNKSDA, Radical Democracy Movement, Progressive Young Nahdliyyin

Intisari: Tulisan ini bertujuan untuk menjelaskan terjadinya reaktualisasi perjuangan Nahdlatul Ulama (NU) atas isu sumber daya agraria melalui kemunculan Front Nahdliyyin untuk Kedaulatan Sumber Daya Alam (FNKSDA) pada 2013. Paper ini menggunakan perspektif teori gerakan demokrasi radikal dari Ernesto Laclau dan Chantal Moufffe dengan mengkaji fenomena perjuangan NU atas sumber daya agraria. Kajian ini menggunakan metode kualitatif dengan variasi studi kasus spesifik tipe single case study. Hasil penelitian ini menunjukkan banyaknya kasus perampasan ruang hidup, ketimpangan kepemilikan sumber daya alam, dan berbagai kondisi agraria lainnya yang menimpa nahdliyyin di berbagai daerah. Berbagai kondisi tersebut disikapi dalam bentuk artikulasi oleh para kaum muda NU yang ternyata telah mengalami perkembangan, yakni tidak sekadar melayangkan kritik terhadap pemerintah, khususnya Orde Baru saat itu. Namun, telah menginisiasi terbangunnya gerakan di masa pasca reformasi dengan meradikalisasi ruang politik selayaknya menuju situasi yang lebih demokratis. FNKSDA bergerak non-struktural dalam tubuh NU. Meski demikian 'budaya dan identitas baru politiknya' justru tampil mewakili watak progresif NU.

Kata Kunci: FNKSDA, Gerakan Demokrasi Radikal, Kaum Muda NU Progresif 


\section{A. Pendahuluan}

Front Nahdliyyin untuk Kedaulatan Sumber Daya Alam (FNKSDA) yang lahir pada 2013 sesungguhnya memiliki dimensi partikular. Gerakan non-struktural dalam tubuh Nahdlatul Ulama (NU) tersebut memiliki tujuan mewujudkan tata kelola sumber daya alam (SDA) atau sumber daya agraria yang berdaulat. Apabila sejarah keterlibatan NU dalam perjuangan agraria sejak kemerdekaan RI ditelusuri akan ditemukan peran ulama-ulama NU dalam perumusan Undang-undang Pokok Agraria 1960 (UUPA), serta keterlibatannya dalam pelaksanaan UUPA yaitu berupa land reform. Fakta tersebut menegaskan sejarah perjuangan agraria pasca kemerdekaan yang tidak hanya identik dengan Partai Komunis Indonesia (PKI) semata, terutama dengan Barisan Tani Indonesia (BTI) seperti yang dipahami secara umum.

Bahkan apabila melacak sejarah perjuangan agraria dalam tubuh NU sebelum UUPA hingga pelaksanaan land reform, organ NU seperti Pertanian Nahdlatul Ulama (Pertanu) telah memiliki banyak cabang. Pertanu memiliki pengaruh hingga 'akar rumput' melalui andilnya pada urusan gerakan seperti tindakan reorganisasi ketika organisasi macet dan cara-cara meningkatkan produksi pertanian. Dengan mulai menelusuri sejarah perjuangan agraria NU dikenal sosok K.H. Zaenal Arifin yang berperan sebagai dewan penasehat Pertanu urusan perkebunan-pertanian tahun 1954 (Luthfi 2018). Beberapa tahun kemudian ia naik menjadi pimpinan DPR-GR dan memiliki kewenangan sebagai pengesah UUPA 1960 (Anggraeni 2016). Secara politis perjuangan atas isu agraria pada masa itu sangat dipengaruhi posisi NU sebagai 'partai politik' dan kedekatannya dengan Sukarno. Bahkan tidak ditemukan banyak pertentangan pada mayoritas politisi NU atas banyak kebijakan presiden Sukarno (Van Bruinessen 1994).

Begitu EraSukarno berakhir, NU tidak lagi dekat dengan penguasa. Naiknya rezim Orde Baru mengakibatkan PKI menjadi partai terlarang pasca gejolak Gerakan 30 September 1965 (G3oS). Terlepas dari kompleksitas peristiwa tersebut, yang perlu disoroti pada rezim Orde Baru ialah pembe- kuan UUPA selama 11 tahun. Begitu pula dengan NU, gerakannya melalui Pertanu lambat laun dilucuti. NU pada masa Orde Baru hanya mengandalkan keputusan-keputusan dalam forum Bahtsul Masail untuk mengontrol pemerintah. Di antaranya melalui Muktamar NU ke-29 tahun 1992 di Bandar Lampung dan Musyawarah Nasional Alim Ulama NU di NTB tahun 1997 yang menyikapi pembebasan tanah dengan dalih kepentingan umum, yang menjadi dalih lahan bisnis pengusaha. Pasca keputusan tersebut ditetapkan kejahatan perampasan tanah atas nama 'pembangunan' maupun 'kepentingan umum' nyatanya tetap saja bergulir.

Hal diskursif yang penting untuk disoroti dalam NU pada masa Orde Baru adalah keputusan 'kembali ke khittah 1926' melalui Muktamar Situbondo tahun 1984. NU kembali pada bentuknya semula sebagai 'organisasi sosial keagamaan atau organisasi kemasyarakatan' bukan 'organisasi politik'. Jika dipahami secara permukaan terdapat bentuk depolitisasi pada NU. Pasalnya sebagian tokoh NU yang berpatron dengan partai politik perlahan menarik diri. Meskipun muncul penegasan, bukannya terdapat depolitisasi dalam NU, namun perubahan arah gerak politik yang berbeda (Van Bruinessen 1994). Singkatnya keluarnya NU dari urusan politik formal memberikan kebebasan aktivis NU untuk melakukan tugas advokasi dan pemberdayaan masyarakat akar rumput serta mengekspos sifat hegemonik Orde Baru (Bush 2009, 102).

Apabila dipandang secara retrospektif, perjuangan masyarakat sipil pada gerakan 'NU kembali ke khittah' lebih sedikit dibicarakan dibandingkan gagasan terkait pluralisme. Tidak ada pula ikhtiar untuk menautkan gagasan pluralisme dengan gagasan keadilan ekonomi dan politik yang menjadi ruh perjuangan masyarakat sipil. Akan tetapi hal tersebut tidak terjadi pada NU saat ini, yang mana menjadikan gagasan pluralisme sebagai isu mainstream pada banyak kalangan nahdliyyin. Dengan demikian, gagasan pluralisme tanpa memahami pertautannya dengan diskursus perjuangan masyarakat sipil, diskursus pembangunan, ataupun diskursus lain yang lebih mendalam akan terasa hampa. 
Merujuk pada gagasan diskursus menurut Laclau dan Mouffe, diskursus tidak bersifat final dalam pengungkapan suatu bahasa, melainkan bertarung dan bertautan dengan 'yang material' (Newlands 2013). Maka, baik diskursus perjuangan masyarakat sipil maupun diskursus pluralisme bertemu pada titik diskursus pembangunanisme Orde Baru yang telah menyangsikan peran masyarakat sipil. Khususnya akibat pembangunan nasional yang bersifat top down, sentralistik, sekaligus mengagung-agungkan 'pertumbuhan ekonomi'. Pluralisme selayaknya berwatak perjuangan. 'Pluralitas garapan bagi gerakan islam di Indonesia yang ada saat ini, pada dasarnya merupakan potensi tersendiri, bila aktualisasinya mampu memenuhi pluralitas pandangan dan wawasan di berbagai aspek kehidupan' (Mahfudh 1994, 123). Pluralisme tidak berhenti dipahami sekadar pembedaan ataupun harmonisasi di antara etnis, agama, atau ras, namun menyangkut pula aspek sosio-ekonominya.

Hak sosial, politik, ekonomi, dan lainnya dari masyarakat sipil dapat dikembalikan melalui demokratisasi. Setelah itu perebutan makna pembangunan dapat dilakukan, sebab arti pembangunan selayaknya tidak hanya bertumpu pada pengetahuan Barat maupun dipreskripsikan oleh lembaga internasional global kepada elit dunia ketiga (Escobar \& Alvarez 2018 2011), seperti yang terjadi di Indonesia pada rezim Orde Baru, bahkan hingga saat ini. Selain itu, berkaitan dengan masa transisi rezim otoritarian ke demokrasi yang dihantarkan oleh 'efek demonstrasi' sebagai praktik revolusi demokratik nyatanya tidak memiliki proyek yang jelas. Justru menurut Harvey, Castellas, dan Amin berimbas pada sekadar restrukturasi kapital sebagai efek krisis, ditunjukkan pada terjadinya kegaduhan dan instabilitas politik (Escobar \& Alvarez 2018). Pasca reformasi menjadi masa sulit bagi gerakan masyarakat sipil, sebab alternatif gerakan yang setidaknya meredusir 'kebebasan' yang cenderung bercorak individualistik maupun berwatak liberal ekonomi belum ditemukan.

Oleh karena itu, ‘kebangkitan' perjuangan agraria dalam tubuh NU yang terwujud pada FNKSDA bukanlah sesuatu yang baru. Akan lebih tepatnya kalau apa yang terwujud pada perjuangan FNKSDA dipandang sebagai sebuah bentuk 'reaktualisasi'. Reaktualisasi tersebut terletak pada terbangunnya kembali suatu gerakan berwatak progresif pada NU seperti yang dulu ditunjukkan oleh Pertanu dan kritik atas relasi serta posisi NU terhadap rezim Orde Baru. Namun kaitannya dengan NU, gerakan FNKSDA memiliki watak khusus sebab perjuangannya lebih berwatak non-struktural daripada struktural. Isu yang diusungnya pun tidak berkaitan dengan pertanian atau lahan namun lebih luas seperti sumber daya alam atau sumber daya agraria.

Dengan demikian, salah satu tujuan FNKSDA yang mewacanakan pengarusutamaan isu tata kelola SDA setelah isu pluralisme dapat dipahami bukan merupakan perebutan ruang isu dalam NU. Penegasan atas pandangan ini terletak dalam (Lembar Kerja FNKSDA 2013, 6) yang menyatakan bahwa 'isu pluralisme yang didorong oleh Abdurrahman Wahid telah melahirkan banyak pemimpin muda di komunitas NU, meskipun sangat sedikit yang mengerucut sampai ke pimpinan politik'. Di sisi lain kaum muda NU saat ini telah mengalami perkembangan, tidak sekadar mengkritik pemerintah, namun telah menginisiasi terbangunnya gerakan. Para kaum muda nahdliyyin telah menemukan kembali perkembangan identitasnya. Identitas tersebut menurut Reyna, Piscitelli, Calderon seperti menulis kembali novel sejarah yang mana mewakili penciptaan gerakan yang benar-benar baru (Escobar \& Alvarez 2018).

Dengan demikian, artikel ini ingin menunjukkan makna 'mengapa terjadi reaktualisasi perjuangan atas sumber daya agraria dalam NU, spesifik dikaitkan dengan kelahiran FNKSDA'. Memperluas studi yang dilakukan Luthfi mengenai 'Sejarah dan Revitalisasi Perjuangan Pertanian NU Melawan Ketidakadilan Agraria' (Luthfi 2018), artikel ini mendalami 'reaktualisasi' perjuangan NU mewujudkan keadilan agraria melalui FNKSDA sebagai 'hegemonic struggle'. Memperluas pula studi Mubarok terkait 'Gerakan sosial lingkungan pemuda NU: Studi pada FNKSDA' (Mubarok 2016), atas hegemonic struggle FNKSDA tulisan ini 
merupakan penelusuran lebih lanjut atas dinamika historis 'kaum muda NU' yang ternyata telah sampai pada upaya membangun 'identitas baru politiknya'. Sehingga studi Nashirulhaq yang membaca generasi muda NU sebagai perjuangan ekonomi-politik (Nashirulhaq 2017), menjadi kurang relevan. Sifat perjuangan kaum muda NU melalui terbentuknya FNKSDA lebih bersifat 'hegemonik', artinya tidak memimpin secara langsung 'identitas kelas' melainkan melalui formasiformasi hegemoni berjuang 'memperkuat identitas kelas'.

Artikel ini spesifik menggunakan perspektif perjuangan demokratik baru dari Ernesto Laclau dan Chantal Mouffe untuk membaca lahirnya gerakan FNKSDA. Praktik perjuangan demokratik baru banyak digunakan untuk membangun analisis atas gerakan sosial di Amerika Latin yang muncul pasca revolusi demokratik. Revolusi demokratik bertujuan meruntuhkan development state yang sentralistik dan otoritarian. Meskipun pada saat yang sama berimbas membuka kran kapitalisme maju dalam bingkai demokrasi liberal. Demokrasi memiliki paradoks, dapat menjadi ancaman ataupun perjuangan (Mouffe 200o). Pada konsekuensi tumbuhnya keragaman identitas akibat demokratisasi, dapat dibangun gerakan dengan agenda yang dapat menerima pluralitas, namun secara simultan harus bersifat 'meradikalisasi demokrasi'. Gerakan ekologi misalnya dapat sekaligus anti-kapitalisme, anti-rasisme, antiotoritarianisme, bahkan teologi pembebasan. Itulah praktik gerakan yang disebut Laclau dan Mouffe sebagai gerakan demokrasi radikal.

Penelitian ini menggunakan metode kualitatif dengan variasi studi kasus, spesifik tipe single case study. Menurut Yin (2009) studi kasus diterapkan ketika tidak terdapat batasan jelas antara fenomena dan konteks. Berfokus pada pencarian makna 'reaktualisasi' perjuangan atas agraria dalam NU, serta didekati dengan perspektif perjuangan demokratik baru Laclau dan Mouffe. Penelitian ini membaca kondisi NU kontemporer pada konteks fenomena gerakan sosial baru, spesifik berkaitan dengan FNKSDA. Penelitian ini dilakukan dari bulan Agustus 2018 hingga Maret 2019. Pengam- bilan data dilakukan melalui pertama, menjadi partisipan pada Musyawarah Nasional FNKSDA II di Pondok Pesantren Al-Itqon, Semarang, pada 2326 Oktober 2018. Kedua, pengamatan yang dilakukan pada media sosial resmi milik FNKSDA dan juga mengikuti beberapa agenda FNKSDA. Ketiga, wawancara mendalam kepada para informan yang dipetakan berdasar perannya dalam FNKSDA, yaitu terdiri dari penggagas pertama FNKSDA, koordinator nasional dan daerah, pegiat FNKSDA, serta PBNU.

\section{B. Terbangunnya Blok Historis:}

\section{Memahami Kerapuhan Identitas Nahdliyyin}

Pada prosesnya, penyematan 'nahdliyyin' pada nama gerakan FNKSDA menuai polemik. Hal ini dikarenakan FNKSDA tidak berafiliasi secara struktural dengan Pengurus Besar Nahdlatul Ulama (PBNU). Argumen-argumen tidak taktis, merepotkan, dan lainnya muncul dalam perdebatan (Komunikasi dengan Dwi Cipta, 29 Januari 2019). Namun pada akhirnya tetap disepakati nama 'Front Nahdliyyin untuk Kedaulatan Sumber Daya Alam'. Pada saat nama tersebut ditetapkan satu tugas gerakan selesai, yakni menentukan kejelasan posisi 'subyek gerakan'.

Identitas 'nahdliyyin' yang dipahami sebagai 'warga NU' ataupun diartikan orang-orang yang mengamalkan nilai-nilai ajaran Islam Ahlussunah wal Jama'ah, berkembang pula menjadi 'identitas politik'. Bila dipahami permukaan, hal tersebut sekadar soal tambahan 'arti', namun di situlah 'identitas' mengalami perkembangan menjadi lebih politis. Sebab subyek dari gerakan diposisikan sebagai struktur yang 'diskursif (Laclau \& Mouffe 1985). Sedangkan makna diskursif menurut Laclau ialah wujud diskursus yang konkret (Torfing 1999). Lebih lanjut paparnya, diskursus bukan sekadar fenomena kebahasaan, daripadanya telah menembus 'yang material'.

Pada makna 'yang material' dapat dikaitkan dengan penelusuran dalam (Lembar Kerja FNKSDA 2013) fakta-fakta berupa rentetan kasus, seperti rencana proyek pembangunan Pembangkit Listrik Tenaga Uap (PLTU) 10.00o Megawatt di Batang, 
Jawa Tengah pada 2013, di mana PLN tidak memiliki dana untuk membangunnya. Ada upaya pelelangan untuk memeroleh dana. Setelah kucuran dana didapatkan dari pihak asing tetap saja proyek tersebut tidak berjalan mulus. Ditemukan konflik antara korporasi dengan pemilik tanah maupun pemilik tanah dengan petani penggarapyang mana mayoritas 'nahdliyyin'. Bahkan bukan saja nahdliyyin yang menjadi korban, namun terdapat pula oknum NU berpengaruh yaitu Habib Luthfi yang memuluskan awal masuknya investor (Lembar Kerja FNKSDA 2013).

Pada kasus lain, bencana industri yang disebabkan oleh PT. Lapindo Brantas berupa semburan lumpur panas yang melenyapkan ruang hidup sebagian besar nahdliyyin di Sidoarjo, dan sekitarnya. Penambangan pasir besi di pesisir pantai Kulon Progo yang mendapat resistensi dari Paguyuban Petani Lahan Pasir (PPLP). Kasus pembangunan bandara baru Yogyakarta yang juga menuai penolakan warga. Perampasan ruang hidup oleh korporasi penambang pasir, TNI, dan pelaku lainnya di Urutsewu, Kebumen. Kasus 'eksploitasi SDA' di Kalimantan, Sumatra, dan daerah lainnya yang menghancurkan lingkungan dan ruang hidup warga.

Realitas banyaknya kasus yang tidak sekadar berkaitan dengan lahan namun eksploitasi SDA yang berimplikasi pada krisis ekologis, perampasan ruang hidup, dan berbagai persoalan lainnya. Beragamnya kasus tersebut banyak ditemukan nahdliyyin sebagai 'korban', dan tidak jarang turut terlibat menjadi 'pelaku' meskipun bukan satusatunya. Lantas di situlah letak 'kerapuhan identitas' nahdliyyin ditemukan.

"Ada banyak titik orang NU mengalami: 'orang Urutsewu tidak sepakat disebut konflik, ia bilang perampasan tanah. Jadi baginya itu bukan konflik tetapi perampasan tanah'. Lebih mudahnya orang sebut NU banyak mengalami masalah agraria." (Komunikasi dengan Bosman Batubara, Penggagas FNKSDA, 14 Februari 2019).

Kerapuhan identitas nahdliyyin ditengarai 'antagonisme' sehingga memerlukan praktik artikulatoris. Praktik artikulatoris secara konkret diwujudkan pada tindakan 'berkumpul', untuk dapat memperjuangkan suatu kepentingan historis (Laclau \& Mouffe 1985). Kepentingan historis ialah kesadaran atas fakta obyektif atau kasus 'yang material'. Tuntutan-tuntutan konkret diperlukan demi mewujudkan kembali identitas yang 'utuh'. Dalam 'antagonisme' dianalogikan, 'petani tidak dapat menjadi petani'. Begitu pula 'nahdliyyin yang tidak dapat sepenuhnya menjadi nahdliyyin'. Hal tersebut merupakan kesadaran atas kondisi 'yang material'.

Berangkat dari kesadaran itulah, awal mula membangun 'blok historis' dilakukan. Melalui pertemuan pada 4 Juli 2013 di Pendopo Hijau LKiS, Yogyakarta, diskusi terkait 'NU dan Tata Kelola SDA' dilaksanakan. Terdapat beberapa lembaga yang turut serta seperti: Lafadl Initiative, Jamaah NU, Lakpesdam Jombang dan Kebumen, Forum Silaturahmi Petani Pesantren (FSPP), PMII Sleman, dan lainnya (Lembar Kerja FNKSDA 2013). Aktoraktor yang mewakili lembaga tersebut rata-rata merupakan 'aktivis muda NU' dari berbagai daerah di antaranya Yogyakarta, Kebumen, Batang, Mandailing Natal, Samarinda, dan lainnya. Akhirnya menyepakati dibentuknya 'gerakan'. Diputuskan pula rencana deklarasi yang dilaksanakan beberapa bulan kemudian di Pesantren Tebuireng, Jombang.

“Kasusnya, materialnya (...) sehingga orang
yang punya kasus, berhubungan dengan agraria
atau lingkungan mereka ingin menyelesaikan,
dan ingin melihat satu peluang dengan ber-
kumpul, maka akan bisa membantu menyele-
saikan kasusnya. Berkumpullah di LKiS tahun
2013, kemudian di Jombang”. (Komunikasi
dengan Bosman Batubara, 14 Februari 2019).

Melalui kesepakatan di LKiSyang memerankan banyak agen dengan berbagai latar belakang lembaga, dan disepakati tindak lanjut berupa inisasi gerakan. Pada saat itulah apa yang disebut oleh Gramsci sebagai ‘blok historis' diciptakan, sebab telah dilakukan praktik artikulatoris yang diwujudkan pada tindakan berkumpulnya agen-agen, yang pada akhirnya membentuk identitas relasional demi perjuangan atas kepentingan historis (Laclau \& Mouffe 1985). Telah ditunjukkan pula kelahiran FNKSDA dimulai dari historis 'yang material' berupa kasus-kasus objektif yang menimpa nahdliyyin. 
Memahami bangunan gerakan FNKSDA lebih lanjut menurut Laclau dan Mouffe berkaitan dengan proses artikulasi terus-menerus atas identitas kolektif, di mana terdapat kepentingan yang sama namun bersifat diskursif (Escobar 2018).

"Ada kejadiannya, ini material, baru menciptakan utopianya. Bukan ada konsep tentang sesuatu yang ideal yang ingin dicapai. Maka ideologinya apa, mencari kemudian, coba-coba. Itu dinamikanya, mencari”. (Komunikasi dengan Bosman Batubara, 14 Februari 2019).

\section{Membangun Formasi-Formasi Hegemonik}

\section{Perkembangan Pemikiran Kaum Muda} NU

Pada pertemuan sebelumnya di LKiS pada 4 Juli 2013 diperoleh kesepakatan tindak lanjut atas inisiasi satu gerakan demi merespon kasus-kasus yang menimpa nahdliyyin. Terdapat waktu beberapa bulan menuju dideklarasikannya FNKSDA dan penamaan gerakan terus diperbincangkan melalui media daring; grup facebook. Proses pembahasan nama gerakan menjadi penting sebab mulai dari situlah arah gerakan dapat mulai terbaca. Di situ pula letak kerja 'ekuivalensi' yang mana penciptaan penanda bukan pembeda dilakukan, akan menggeser identitas dari sekadar 'literal' menjadi simbol posisi tertentu yang lebih 'kontekstual' (Laclau \& Mouffe 1985).

Hal tersebut mempertegas pemahaman gerakan sosial menurut Laclau \& Mouffe yang tidak mengistimewakan subyek tertentu dalam perjuangan. Jika dalam gerakan sosial lama lebih mengistimewakan tugas identitas ekonomi yakni kelas petani, kelas buruh, dan sebagainya. Dalam gerakan sosial baru menurut Dagnino, Alvarez, dan Escobar lebih mengedepankan identitas yang lebih luas demi menunjang keterlibatannya atas bentuk baru politiknya, serta berkaitan dengan kontribusi serta kemampuan dalam membangun sosiabilitasnya (Alvarez 2018). Maka, muncullah nama 'front' pada FNKSDA.

"Front menandakan tiga hal, berupa garis depan mainstreaming isu ketimpangan sumbersumber agraria, kedua bertendensi progresif, ketiga komposisinya beragam namun memiliki visi politik yang sama (...) Penting menamakan front untuk membedakan, karena NU selalu diidentikan dengan arti moderat yang sangat peyoratif. Tengah yang kurang ambil posisi. Moderatisme tidak begitu seharusnya. Posisinya di sini berdasarkan melihat situasi, kondisi, fakta-fakta konkret di masyarakat dan tidak bisa kemudian tidak mengambil sikap". (Komunikasi dengan Roy Murtadho, Koordinator Nasional FNKSDA, 14 Februari 2019).

Merujuk pernyataan tersebut 'formasi hegemoni’ mulai terbangun. Berhubungan dengan pemahaman atas suatu organisasi keagamaan misalnya dapat melampaui praktik-praktik tradisionalnya, meski tidak jarang menemui pertentangan (Laclau \& Mouffe 1985). Pemaknaan 'moderat' dalam NU yang diartikan tengah-tengah dan berakhir tidak berpihak, khususnya dalam membaca persoalanpersoalan kemasyarakatan. Realitas kondisi tersebut ditampilkan pada organisasi masyarakat islam seperti NU dan Muhammadiyah yang memaknai moderat sebagai 'bukan ini' atau 'bukan itu', sehingga tidak tegas memosisikan identitasnya, lebih sesuai disebut pseudo-moderat (Burhani 2016).

"Muncul ketidakpuasan pada struktural NU. Masifnya jamaah nahdliyyin mengalami penyingkiran, marjinalisasi. Tidak banyak muncul pembelaan-pembelaan terhadap mereka, sehingga mereka mempertanyakan umat mengapa tidak dibela. Justru di beberapa tempat lebih dekat dengan pihak yang memberikan penekanan kepada warga". (Komunikasi dengan Muchamad Muslich, Koordinator Nasional FNKSDA, 18 Februari 2019).

Pada titik tersebut, 'penanda' diciptakan oleh para kaum muda NU. Terdapat pembedaan makna moderat antara kaum muda NU dengan makna moderat yang dipahami secara umum oleh NU. Terdapat pula realitas yang menampilkan 'perkembangan pemikiran lebih lanjut' kaum muda nahdliyyin.

"Ini perkembangan baru, dalam artian ada kesadaran, tidak bisa taat dengan pemerintah kalau ternyata dampaknya tidak adil untuk rakyat. Bisa keburukan untuk alam. Artinya baru, setelah ada generasi baru di sekolahsekolah ini. Kalau dulu dengan pemerintah taat. 
Pemerintah mau membuat ini, oh untuk kebaikan. Tidak kalau saat ini, dianalisis, ini bukan pemerintah. Hanya sekelompok orang sebenarnya yang memanfaatkan". (Komunikasi dengan Hairus Salim, Penggagas FNKSDA, 4 Februari 2019).

Kaum muda NU saat ini dapat diandaikan seperti penjelasan (Murtadho 2015) atas sedikit genealogi pemikiran Abdurrahman Wahid yang terkesan Gramsci. Gramsci sebagai pengusung konsep hegemoni telah dilampaui oleh Laclau dan Mouffe. Hegemoni bukan lagi konsep dari bentuk-bentuk dominasi yang menyeluruh. Akan tetapi melalui subyek dan produksi formasi hegemonik terdapat perjuangan hegemoni. Seperti kondisi kaum muda NU saat inilah, satu langkah lebih lanjut, hegemoni telah dilampaui sebagai strategi perjuangan.

"Kesadaran anak-anak sekarang lebih maju untuk gerakan, mereka memiliki prasyarat-prasyarat mendukung movement, kalau zaman Abdurrahman Wahid tidak, memberikan kritik saja ke Orde Baru". (Komunikasi dengan Roy Murtadho, 19 Februari 2019).

Sampailah pada yang disebut rantai ekuivalensi untuk membangun pembedaan melalui batasbatas dalam dirinya sendiri semakin 'jelas'. Diwujudkan pada deklarasi Front Nahdliyyin untuk Kedaulatan Sumber Daya Alam (FNKSDA) pada 8 Desember 2013 di Pesantren Tebuireng, Jombang oleh 200 lebih kaum muda nahdliyyin (Tebuireng Online 2013a). FNKSDA merupakan 'wadah koordinasi antara Jamaah NU yang memiliki kehirauan mengenai permasalahan konflik pengelolaan SDA' (FNKSDA 2013). Melalui deklarasi, formasi hegemoni yang pertama tegas diciptakan. Posisi FNKSDA yang tidak terikat struktural NU memungkinkan mainstreaming isu kedaulatanSDA setidaknya berada pada dua titik yaitu 'kaum muda NU', bahkan NU secara keseluruhan baik jamaah maupun jam'iyah.

Di sisi lain, formasi hegemoni dapat berfungsi untuk membaca posisi FNKSDA terhadap NU. Dengan identitas 'nahdliyyin' yang tetap disematkan pada nama gerakan dan telah melalui 'ekuivalensi'. Maka, FNKSDA tidak vis-à-vis dengan NU struktural, namun memiliki peran mendorong struktural, begitulah watak perjuangan hegemonik pertama ditampilkan. Penegasan tugas-tugas kemasyarakatan ditunjukkan, selaras dengan seruan kembalinya NU ke khittah 1926 yang selayaknya dielaborasi terus-menerus bagi kepentingan nahdliyyin.

"Kaitannya khittah, harusnya diurus oleh NU. Sangat kompatibel sebenarnya dengan khittah. Justru dengan khittah, seperti ini yang harus dilakukan NU. Selain mengembangkan masjid, sekolah, pesantren, juga harus membela kaum miskin dan yang dimiskinkan, sesuai dengan khittah yang dituliskan oleh K.H. Hasyim Asy'ari”. (Komunikasi dengan Hairus Salim, 4 Februari 2019).

Berangkat dari hal tersebut NU sebagai salah satu organisasi masyarakat sipil terbesar sebenarnya memiliki sifat 'demokratis'. FNKSDA sebagai gerakan non-struktural tetap dapat 'bergerak' dan tidak menuai 'larangan' dari struktural. Di sisi lain, upaya FNKSDA termasuk canggih dalam melakukan 'ekuivalensi', sebab gerakannya tidak menciptakan 'pembeda' melainkan 'penanda' dalam tubuh NU. Penanda tidak menimbulkan demarkasi mendasar, justru membangun peluang untuk melakukan perjuangan hegemonik.

"Kalau dikatakan alternatif bisa sebenarnya. Keinginannya mendorong struktural juga untuk melakukan masukan atau kritik. Maka, sekarang bagaimana berusaha membagikan apa yang diusung oleh front ke struktural agar menyambung". (Komunikasi dengan Muchamad Muslich, 18 Februari 2019).

Lantas berkaitan dengan ketidakpuasan kaum muda nahdliyyin terhadap NU struktural yang menurut penelitian (Mubarok 2016, Nashirulhaq 2017) sebagai salah satu latar belakang kelahiran FNKSDA perlu penjelasan lebih lanjut. Sebab faktafakta 'objektif atau kasus material' yang disikapi kaum muda NU yang ternyata telah mengalami perkembangan yang menjadi titik awal dibentuknya FNKSDA. Lebih fair kemudian, bilamana membaca lebih lanjut kondisi kaum muda NU, serta kondisi NU struktural dikaitkan dengan aspek sosial-politik yang lebih besar. 


\section{Membaca Kondisi NU Struktural}

Sebelum dideklarasikannya FNKSDA terdapat pertemuan dengan ketua PBNU K.H. Imam Aziz (Lembar Kerja FNKSDA 2013). Menurut Aprianto melalui K.H. Imam Aziz isu agraria bisa kembali masuk menjadi perhatian PBNU (Luthfi 2018). Pada proses menuju deklarasi terdapat pembahasan mengenai posisi PBNU atas isu SDA. Pembahasan mengenai kesepakatan Munas Alim Ulama NU pada 2012 yang merekomendasikan pada pemerintah atas urgensi renegosiasi perusahaanperusahaan tambang masuk dalam rangkaian diskusi sebelum deklarasi (Tebuireng Online 2013b). PBNU sesungguhnya telah memiliki beberapa ketetapan terkait SDA sebelum diresmikannya FNKSDA.

"Secara normatif fatwa-fatwa sudah ada sejak dahulu di NU, namun yang belum ialah terkait solidaritas". K.H. Imam Aziz, Ketua PBNU, dalam Musyawarah Nasional II FNKSDA: Menegakkan Daulat Rakyat dalam Perjuangan Agraria, Demokrasi, dan Anti-Kapitalisme di Indonesia.

Pasca-reformasi beberapa fatwa terkait SDA telah ditetapkan oleh PBNU. Di antaranya melalui Muktamar NU ke 30 di Kediri 1999yang membahas mengenai 'hak atas tanah' dan Munas Alim Ulama NU pada 2012 yang mendesak pemerintah untuk renegoisasi perusahaan-perusahaan tambang. Ketetapan-ketetapan tersebut merupakan keputusan tertinggi yang tidak dapat dibantah dan harus dilaksanakan mulai dari PBNU hingga ranting NU.

"Muktamar itu kurang besar apa. Muktamar sudah tidak ada yang bisa membantah. Kiai, Gusgus, siapapun itu tidak bisa membantah". (Komunikasi dengan K.H. Imam Aziz, 6 Februari 2019).

Keputusan dalam muktamar maupun munas alim ulama NU diserahkan kepada negara sebagai rekomendasi maupun 'desakan' untuk berbagai kebijakan. Rekomendasi-rekomendasi NU berangkat pula dari justifikasi nilai-nilai keagamaan dalam proses penetapannya. Meskipun tidak sedikit rekomendasi-rekomendasi tersebut yang diabaikan oleh negara. Realitas kondisi politik yang lebih besaratas kebijakan-kebijakan yang tidak berpihak pada masyarakat 'akar rumput' ditampilkan. Padahal PBNU dalam beberapa persoalan SDA sesungguhnya turut andil, akan tetapi situasi sosialpolitik yang lebih besar berpengaruh.

"Jadi tanah-tanah HGU yang dipakai ada batasannya, sekarang ini entah berapa tahun. Itu sudah tidak boleh dipakai lagi yang untuk perkebunan sawit. Nanti kalau habis, itu rekomendasi NU, tidak usah perpanjang. Untuk apa, bagikan pada rakyat". (Komunikasi dengan K.H. Imam Aziz, 6 Februari 2019).

Dengan demikian, kekecewaan atas NU struktural dapat dipahami sebagai ketidakpuasan atas tidak adanya 'solidaritas' dalam lingkungan NU. Relasi struktural NU tidak selalu dipahami vertikal. Antara pusat dengan cabang-cabang kadang kala memiliki ketetapan yang berbeda. Persoalan di berbagai daerah merupakan bagian dari tanggung jawab cabang. Ketika polemik terkait SDA terjadi, realitasnya tidak sedikit cabang-cabang maupun NU setempatyang abai atas ketetapan tertinggi yang disepakati dalam PBNU.

\footnotetext{
"Kita tetap berusaha supaya ada payung hukum agamanya. Jadi bukan soal untung-rugi, tapi pahala dan dosa. Kalau untung-rugi undangundang negara bisa dipakai, ini soal dosa dan pahala. Kalau membela rakyat itu pahala (...) orang-orang 'itu' tidak paham". (Komunikasi dengan K.H. Imam Aziz, 6 Februari 2019).
}

\section{Kompatibilitas Kategori Perkembangan Pemikiran Kaum Muda NU Menuju Gerakan}

Pemahaman perkembangan pemikiran kaum muda NU dalam kenyataannya tidak homogen. Perubahan pemikiran kaum muda NU yang berlangsung mulai kurun waktu 1970-an sebagai cara baru untuk mengkritisi Orde Baru, pada saat yang sama menurut (Murtadho 2015) tidak sedikit pemikir-pemikir islam saat itu yang terseret pada gagasan pembangunan yang developmentalistik. Ditampilkan dan dikaitkan dengan kemunculan kritik pada van Bruinessen yang tidak dapat memilah gagasan-gagasan pemikir islam, yang cenderung pada liberal modernis dan islam emansipatoris misalkan (Al-Fayyadl 2015). Sehingga makna 
perubahan pemikiran kaum muda NU pada kurun 1970-an belum 'clear' yang mana kategori pemikiran islam yang sesuai dengan semangat perjuangan 'masyarakat sipil'.

Pemikiran 'kiri islam' oleh Hassan Hanafi yang bermakna pembebasan dari ketertindasan atau bersifat emansipatoris sangat berbeda dengan pemikiran islam liberal (Misrawi 2002, Al-Fayyadl 2015). Keduanya bertendensi pembebasan, namun kiri islam menghendaki 'transformasi kesadaran individual menuju tindakan kolektif. 'Islam liberal yang selalu memosisikan diri melawan tradisi cenderung bersifat elitis' (Misrawi 2002). Islam liberal dapat terjebak pada tataran liberal ekonomi, akibat 'pembebasan' berada ranah cara berpikir.

Selain itu, islam liberal meletakkan demokrasi dan pluralisme sekadar tujuan dari perubahan (Misrawi 2002). Sedangkan kiri islam melampaui daripadanya, melalui kritisisme tradisi yang bersifat kaku, dapat dilakukan transformasi sosial. Berangkat dari hal tersebut perubahan pemikiran kaum muda NU yang sesungguhnya berupa proses 'liberasi agama' terbagi atas dua kubu yakni kalangan islam liberal dengan terbentuknya Jaringan Islam Liberal (JIL). Serta, kalangan post-tradisionalisme yang berkehendak mempertanyakan tradisi namun secara simultan menggunakan pula tradisi sebagai perjuangan, ditunjukkan dengan kemunculan Lakpesdam NU, LKiS, dan lainnya (Bisri 2012).

Baik islam liberal maupun post-tradisionalis meskipun bertendensi pada pemikiran islam yang membebaskan namun tetap memiliki demarkasi yang mendasar. 'Islam liberal orientasinya lebih pada dataran makro-struktural, tapi post-tradisionalis lebih berorientasi pada pemberdayaan masyarakat dengan gerakan emansipatorisnya' (Bisri 2012, 1). Sangat sukar mengatakan FNKSDA sebagai pertalian dari perkembangan pemikiran dari kalangan post-tradisionalis, sebab beragamnya pemikiran kaum muda NU pasca-reformasi.

Akan tetapi, menilik agen-agen di awal berdirinya FNKSDA dapat ditemukan peran di antaranya Lakpesdam, LKiS-yang memperkenalkan kiri islam, dan lainnya. Melibatkan pula K.H. Imam Aziz yang merupakan salah satu pendiri LKiS. Selain itu, jika dikembalikan pada pencarian atas wacana pemikiran islam yang berhadapan dengan hegemoni Orde Baru dengan model pembangunannya yang developmentalistik. Selaras dengan alternatif pembangunan pasca runtuhnya Orde Baru berupa 'pemberdayaan masyarakat' (Widayanti 2012). Maka, FNKSDA kompatibel dengan gagasan kalangan post-tradisionalis sejak awal, yang menekankan pentingnya pengembalian peran masyarakat sipil agar memiliki kekuatan dan daya tawar seimbang dengan negara. Sesuai dengan gagasan pemberdayaan masyarakat turunan dari perspektif anti-developmentalisme, yang salah satunya menghendaki dibangunnya 'gerakan massa'.

Berbeda dengan perkembangan makna pemberdayaan masyarakat sebagai antitesis pembangunanisme Orde Baru, yang nyatanya terseret pula arus developmentalisme dengan munculnya program-program pembangunan dari negara misalkan PNPM (Program Nasional Pemberdayaan Masyarakat) dan pendanaannya disokong lembaga finansial global seperti Bank Dunia. Sehingga muncul model pemberdayaan masyarakat melalui praktik community driven development, community based development, dan lainnya (Widayanti 2012). Pemberdayaan masyarakat turunan dari perspektif developmentalisme menuntut masyarakat sesuai dengan struktur.

Sedangkan sifat dari pemberdayaan masyarakat yang anti-developmentalisme menghendaki terbangunnya gerakan yang melawan 'sistem'. Akar dari ketidakberdayaan adalah 'sistem' yang menindas, sehingga berkehendak menciptakan yang disebut Faqih berupa ekonomi tanpa eksploitasi, politik tanpa represi, dan budaya tanpa hegemoni (Mushoffa 2015, Widayanti 2012). Sejalan dengan proses transformasi sosial menurut Hassan Hanafi, yakni setelah melakukan pembacaan 'kritis' tradisi-tradisi (Misrawi 2002).

"FNKSDA adalah eksperimen atau penerjemahan dari teologi pembebasan, mengapa masuknya agraria. Alasan pertama, sebagai landasan pembangunan, tidak mungkin melakukan pembangunan kalau belum ada land reform, apapun bentuk land reform. Kalau yang diperjuangakan ini populistik. Orang NU tidak 
perlu khawatir, ini bukan reforma agraria

Marxistis." (Komunikasi dengan Roy Murtadho, 19 Februari 2019).

Merujuk pada penjelasan tersebut produksi formasi hegemoni melalui ekuivalensi kembali diciptakan. Ditunjukkan pada pemaknaan 'agama dalam bentuk yang tradisional hanyalah sebuah ilusi, namun jika ditampilkan dalam bentuk yang membebaskan dapat menjadi kekuatan yang mengagumkan' (Engineer et al. 1999, 3). Melampaui dari sekadar tradisi berupa ibadah misalkan, dan menegaskan kembali tugas profetik agama sebagai kekuatan pembebasan dari ketertindasan, agama kemudian melekat pada yang material. Pemahaman agama yang lekat pada 'yang material' dapat menjahit realitas kondisi sosial-politik yang ada.

Gerakan FNKSDA memosisikan diri sebagai gerakan progresif yang berangkat dari ajaran agama dengan tujuan membebaskan nahdliyyin dari ketertindasan sistemik. Digambarkan pada kegiatan FNKSDA seperti istighosah akbar bersama warga yang dirampas ruang hidupnya di Kendeng, Kebumen, Kulon Progo dan lainnya. Bentuk-bentuk kegiatan lain di antaranya Pesantren Agraria, Ngaji Ekologi Politis, Ngaji Agraria. Muncul pula pemahaman atau ajaran keagamaan yang lekat dengan aspek sosio-ekologis seperti fiqh lingkungan, sholawat marhaen, sholawat anti-oligarki, dan lainnya.

Di sisi lain, FNKSDA hadir sebagai gerakan yang sekaligus meradikalisasi 'demokrasi'. Pada dinamika demokratisasi, ditandai peristiwa reformasi yang berupaya meruntuhkan yang disebut (AlFayyadl 2015) sebagai 'oligarki terbatas yang dibangun oleh kapitalisme negara' yaitu Orde Baru, nyatanya belum tercapai. Demokrasi bercorak popular sovereignty yang diharapkan justru tercebur pada sistem demokrasi yang liberal. Itu mengapa demokrasi perlu diradikalisasi (Mouffe 200o).

Kapitalisme maju sebagai lawan dari perjuangan demokratik baru tengah dihadapi (Laclau \& Mouffe 1985). 'Efek demonstrasi' sebagai praktik demokratisasi hanyalah 'restrukturasi kapital'. Pemerintahan Orde Baru yang otoritarian dengan tata kelola pemerintahannya yang sentralistik pasca-demokratisasi memang telah runtuh. Digantikan dengan tata kelola pemerintahan yang desentralistik. Namun, sistem demikian nyatanya hanya melanggengkan 'oligarki terbatas' menjadi 'oligarki kolektif melalui demokrasi elektoral (Maimunah 2019). Relasi antara politik dan pebisnis tambang misalkan, sebagai salah satu realitas 'oligarki' tidak hanya berada di lingkup pemerintah pusat seperti yang dibangun Orde Baru bersama jaringan bisnisnya. Namun, penyerahan kewenangan kebijakan kepada pemerintah daerah berimplikasi atas perluasan relasi antara politik dengan pebisnis di daerahdaerah.

Sehingga dalam konteks kapitalisme maju yang salah satunya digambarkan dengan kemunculan oligark-oligark ${ }^{1}$, Roscher memiliki pemahaman bahwa 'alam' menghasilkan berbagai sumber daya yang 'bernilai', namun 'nyaris tidak bernilai tukar' (Marx 2004). Maka, kasus objektif seperti perampasan dan perusakan lahan hijau seluas kurang lebih 900 ha untuk kepentingan penambangan emas di Tumpang Pitu, Banyuwangi, yang melibatkan pula anak perusahaan dari birokrat sekaligus korporat Sandiaga Uno (FNKSDA 2018a). Realitas tersebut ialah salah satu bentuk kapitalisme maju.

Kapitalisme maju tidak hanya berada pada dataran relasi produksi internal di pabrik-pabrik yang digambarkan oleh Marx. Namun berkelindan dalam struktur sosial dan politik (Laclau \& Mouffe 1985). Dikaitkan dengan 'eksploitasi alam', ketika SDA dikeruk, menurut Roscher pada tindakan itulah nyaris tidak ada 'nilai tukar' untuk mengambil hasil alam atau tidak terdapat nilai tukar yang sebanding (Marx 2004). Saat SDA digunakan oleh masyarakat khususnya petani, terdapat proses pemanfaatan alam sekaligus pelestarian atas 'nilai'. Sementara, ketika lahan 'dilipatgandakan nilai kapitalnya’ pada kurun temporer dengan diambil hasil alamnya untuk kepentingan pertambangan. Implikasinya berupa kehancuran atas nilai dari SDA

${ }^{1}$ Rilis (JATAM 2019) dan (Siti Maimunah 2019) menunjukkan kaitan Oligarki Tambang di Balik Pemilu 2019, kedua pasangan calon dalam Pilpres 2019 berkaitan dengan para pebisnis tambang dan mendapatkan dana kampanye dari para pebisnis tersebut.Dirilis pula namanama segelintir oligark yang menguasai industri ekstraktif di Indonesia hingga ke daerah-daerah. 
yang selayaknya dilestarikan. Sedangkan kegiatan penambangan hanya mengambil 'nilai' dari SDA, namun tidak memiliki mekanisme 'melestarikan nilai'.

Di sisi lain, berkenaan dengan kondisi sosialpolitik yang seharusnya lebih demokratis dengan corak demokrasi popular sovereignty atau kedaulatan rakyat. Realitas yang terjadi justru terseret konteks 'kedaulatan' seluas-luasnya, khususnya atas kepemilikan SDA yang dikuasai segelintir oligark. Alternatif pembangunan yakni 'pemberdayaan masyarakat' yang diturunkan dari perspektif antidevelopmentalisme belum menemukan titik temu, sebab rancangan pembangunan dari negara masih mengacu 'pertumbuhan ekonomi'. Ditunjukkan pada upaya pemerintahan presiden Susilo Bambang Yudhoyono melalui MP3 EI (Master Plan Percepatan Pembangunan Ekonomi Indonesia) misalkan, yang didorong demi 'percepatan pertumbuhan ekonomi', yakni melalui 'energi' untuk industri. Akhirnya, jika ditarik pada konflik-konflik SDA di tingkat lokal, sebetulnya hanya ekses dari MP 3 EI (Lembar Kerja FNKSDA 2013). Maka, FNKSDA muncul dan bertindak mengisi kekosongan atas tidak adanya alternatif gerakan pada persoalan yang kompleks tersebut.

"Orang saling tahu sekarang ini korban tiga kali: korban politik, reformasi, dan korban tidak adanya alternatif di zaman reformasi". (Komunikasi dengan Roy Murtadho, 19 Februari 2019).

\section{Hegemonic Struggle: FNKSDA sebagai Gerakan dengan Identitas Massa}

Bersamaan dengan dideklarasikannya FNKSDA pada 8 Desember 2013 di Jombang, ditentukan 'sikap' awal FNKSDA. Di situlah formasi-formasi hegemoni 'jelas' ditampilkan. Melalui 'Resolusi Jihad Jilid II: Mempertahankan Tanah Air dari Rongrongan Kapitalisme Ekstraktif, FNKSDA menyerukan kepada pertama negara, kedua PBNU, dan ketiga nahdliyyin serta warga negara secara keseluruhan untuk mempertahankan tanah air dari rongrongan kapitalisme ekstraktif.

Ketiga ranah tersebut adalah 'formasi' di mana FNKSDA dapat berjuang berhadapan dengan segala bentuk kapitalisme maju khususnya 'kapitalisme ekstraktif. Pada hegemonic struggle yang paling menentukan dalam perjuangan melawan kapitalisme adalah tidak tunggalnya formasi hegemoni. Ditunjukkan pada posisi FNKSDAyang tetap bagian dari NU namun berupaya mendorong NU struktural demi pembebasan nahdliyyin dari bencana ekologis akibat kapitalisme ekstraktif.

Pasca diresmikannya FNKSDA, dapat ditelusuri dalam PBNU telah ditetapkan dua kesepakatan besar terkait SDA pertama, Muktamar NU ke-33 tahun 2015 yang dilaksanakan di Jombang yang membahas mengenai SDA (PBNU 2015). Eksploitasi terhadap SDA di Indonesia adalah haram (Alhafiz 2015). Saat proses muktamar dilaksanakan, kaum muda nahdliyyin menyelenggarakan Musyawarah Besar Kaum Muda NU. Pembahasan dalam musyawarah tersebut di antaranya 'Politik Agraria dan Konflik SDA', yang mana FNKSDA berperan dalam berjalannya diskusi. Keseluruhan hasil diskusi diserahkan ke PBNU untuk ditindaklanjuti dalam Muktamar.

Selain itu kedua, Konferensi Besar dan Munas Alim Ulama NU di Lombok tahun 2017yang khusus membahas terkait isu keumatan, tidak seperti muktamar di mana terdapat agenda pilih-memilih pengurus, menjadikan 'Reforma Agraria' sebagai salah satu prioritas kajian (PBNU 2017).

"Jadi keputusan NU yang luar biasa itu soal reforma agraria. Pemerintah harus mengutamakan, dengan skema apapun, bagi kelompokkelompok miskin. Maka misalkan, kalau hutan atau apapun direncanakan untuk membuat pabrik, atau apa, yang diutamakan rakyat dulu". (Komunikasi dengan K.H. Imam Aziz, 6 Februari 2019).

Selain keputusan di tingkat pengurus besar, di daerah-daerah tetap didorong agar ketetapannya sejalan dengan keputusan di PBNU. Diwujudkan pada langkah FNKSDA Jember, PCNU Jember, PMII Jember, PWNU Jatim serta Bupati Jember Faida, bersama-sama menuntut pencabutan SK Kementrian ESDM NO 1802 K/30/MEM/2018yang mana terlampir wilayah izin usaha pertambangan (WIUP) emas blok Silo (FNKSDA 2018b). Melalui sidang non litigasi majelis pemeriksa sidang memutuskan perlunya pencabutan keputusan Menteri 
ESDM tersebut (Zuhro dan Hakim 2019).

Lembaga Bahtsul Masail PCNU Jember pada November 2018 mengambil sikap dengan menetapkan fatwa 'haram' penambangan emas di blok Silo, yang akan menggunakan 4000 ha lebih lahan (NU 2019). Di mana lahan tersebut terancam rusak dan tidak dapat digunakan untuk pertanian jika penambangan tetap digulirkan. Pada keberhasilan perjuangan tersebut ditemukan wujud tidak tunggalnya formasi hegemoni. Dalam perjuangan atas sumber daya agraria terdapat dorongan langsung dari mayoritas nahdliyyin di Silo, upaya pengurus NU setempat, serta dorongan dari pemerintah kabupaten yang berpihak dan dapat menangkap suara penolakan dari masyarakat Silo.

Kecanggihan gerakan beridentitas massa pun ditampilkan (Laclau \& Mouffe 1985, Escobar \& Alvarez 2018). Identitas massa yang ditunjukkan pada FNKSDA tentu berbeda dengan gerakan identitas massa pada tradisi gerakan sosial lama yang mengistimewakan identitas ekonomi seperti: kelas buruh, kelas petani, dan lainnya. FNKSDA juga merupakan gerakan beridentitas massa namun strategi perjuangannya bersifat hegemonik. Hal tersebut dapat dipahami bilamana menilik agenagen pertama yang berperan dalam kelahiran FNKSDA. Agen-agen selain sebagai jam'iyah ataupun jama'ah NU, mereka juga merupakan akademisi, peneliti, kiai, santri, dosen, geolog, penulis, seniman, dan sebagainya. Namun kemudian melalui 'deklarasi', telah dilalui 'enumerasi'.

Enumerasi yang berfungsi untuk menyebutkan makna suatu kelas seperti kelas buruh, kelas petani, dan lainnya, pada tradisi perjuangan demokratik baru dipakai untuk memahami 'keragaman' dari subyek-subyek (Laclau \& Mouffe 1985). Dikaitkan dengan kondisi kaum muda nahdliyyin saat iniyang telah mengalami perkembangan pemikiran dan berimbas pada beragamnya isu-isu yang digeluti nahdliyyin seperti kebhinekaan, pluralisme, toleransi, dan sebagainya (Nashirulhaq 2017). Menilik pula kantong-kantong nahdliyyin di perdesaan atau pinggiran, yang mana kondisi sosio-ekologisnya telah berubah. Dijelaskan Tjondronegoro bahwa telah terjadi perubahan pembangunan pertanian Indonesia dimulai pada Orde Baru.
Ditandai pada loncatan perubahan sistem menuju modernisasi pertanian, tanpa perubahan struktur agraria. Di sisi lain, menguntungkan dalam peningkatan produksi pertanian, namun lebih banyak yang menikmatinya hanya petani kaya, sedangkan petani kecil dan buruh tani semakin terdesak dan dirugikan (Hüsken 1998).

Maka ditunjukkan bahwa antagonisme pada dataran kelas dan antagonisme dataran massa menjadi berbeda, itu mengapa 'enumerasi' tetap perlu dilakukan. Implikasinya adalah gerakan FNKSDA tampil sebagai organ terbuka yang beridentitas massa, namun strategi perjuangannya bersifat hegemonik. Serta identitas politiknya lebih menonjol, daripada identitas ekonominya yang sebetulnya samar (Laclau \& Mouffe 1985). Sehingga FNKSDA memang tidak memimpin langsung 'kelas' namun berfungsi memperkuat identitas kelas, dan tetap dapat berjuang pada 'dataran kelas'.

\footnotetext{
"Orang-orang kebumen banyak yang tahu, mereka merasa ikut mendirikan (...) ada sejarah front di situ. Kebumen paling terjaga karena ada front di dalamnya. Jadi, mereka merasa front adalah organisasi terbaik untuk mereka ke depannya, ada kegiatannya, dan merasa ditanya terus. Sehingga mereka tetap aktif sampai sekarang." (Komunikasi dengan Bosman Batubara, 14 Februari 2019).
}

Selain itu, identitas 'nahdliyyin' yang dipahami tidak sekadar literal melainkan kontekstual menjadi 'identitas politik' sah-sah saja digunakan. Kondisi saat ini menggambarkan wujud dari 'budaya dan identitas politik baru' pada nahdliyyin yang ingin dibangun pasca keputusan NU kembali ke khittah 1926.

"NU sebetulnya didirikan untuk kepentingan
kemaslahatan umat. Dulu yang kita tentang
penjajah, sekarang pemerintah sendiri, tetapi
cara-cara kerjanya seperti penjajah. Kompeni-
kompeni yang kita tentang. Kalau masih di NU
mestinya harus paham. NU didirikan untuk
kepentingan masyarakat. Selama ada hal-hal
yang tidak sejalan dengan kehidupan masya-
rakat, kita pasti akan menentang". (Komunikasi
dengan K.H. Imam Aziz, 6 Februari 2019).

Gagasan Melluci yang hanya melihat kemunculan gerakan sosial yang selalu terkait 
dengan aliran sejarah terdahulu, tanpa melihat karakter, dan orientasi kolektif yang berubah terpatahkan (Escobar \& Alvarez 2018). Sebab antagon nahdliyyin saat ini adalah segala bentuk kapitalisme khususnya 'kapitalisme ekstraktif. Perjuangan yang diusung FNKSDA untuk mewujudkan kedaulatan SDA lebih luas lagi cakupan isunya, daripada soal-soal lahan ataupun pertanian yang diperjuangan Pertanu pada masa Era Sukarno. Begitu pula dengan kaum muda NU yang telah mengalami perkembangan, sebab secara simultan NU juga telah memiliki arah gerak politik yang berbeda. Gerakan FNKSDA hadir pada kondisi-kondisi 'khusus' yang tidak dialami oleh NU sebelumnya.

"Yang dimusuhi kita sebenarnya adalah sistem kapitalisme yang didekatkan dengan Marx, barangkali tidak. Ini NU, karena kesadaran. Ini wabah yang menggerogoti masyarakat-masyarakat Indonesia, khususnya orang-orang pinggiran, lagi-lagi orang-orang NU”. (Komunikasi dengan Odent Muhammad, Koordinator Daerah FNKSDA Yogyakarta, 18 Februari 2019).

Gerakan FNKSDA lebih leluasa untuk berjejaring di daerah-daerah, melalui identitas baru politiknya'. Serta lebih luwes membangun sosiabilitasnya. Sehingga terciptalah relasi-relasi dengan banyak organ di antaranya WALHI, LBH, Kontras, Kristen Hijau, JATAM, dan organ lainnya, yang dimanifestasikan pada pelaksanaan kegiatan bersama seperti diskusi, sekolah, pernyataan sikap, dan sebagainya. Meskipun FNKSDA mengusung identitas nahdliyyin, namun agenda-agendanya tetap beragam. Ditampilkan pada orientasi atau sebutan gerakannya sebagai gerakan ekologi, antidevelopmentalisme, anti-kapitalisme, bahkan teologi pembebasan.

Tugas dari gerakan selanjutnya ialah terus membangun aliansi, menciptakan aktor baru, bahkan pada tindakan yang lebih radikal terhadap demokrasi adalah bertransformasi menjadi 'partai' (Laclau \& Mouffe 1985). Menelusuri rilis sikap para santri di antaranya dari FNKSDA yang menyatakan golput pada perhelatan pemilu 2019, serta menyuarakan perlunya membangun 'politik alternatif (Affiat 2019). Potensi berupa terciptanya 'partai' ditampilkan. Perjuangan FNKSDA pada kondisi yang selayaknya lebih demokratis ini berada pada koridor demokrasi bercorak popular sovereignty.

Sehingga, "Sudah 22 di seluruh Indonesia. Sampai Maluku, Batam, dan itu organisasi yang dibiayai sendiri. Organisasi muncul, aktor muncul, agenda muncul". (Komunikasi dengan Dwi Cipta, Pegiat FNKSDA, 29 Januari 2019).

Namun, terdapat tantangan yang biasanya dihadapi oleh gerakan dengan identitas massa sebab perannya dalam hegemonic struggle sesungguhnya 'eksterior' (Laclau \& Mouffe 1985). Hegemoni bersifat semu atau parole, sedangkan 'kelas' seperti petani 'nyata atau langue.' Perjuangan hegemoni dapat menguatkan identitas kelas, namun kemudian muncul salah satunya berupa kegamangan 'siapa pemimpin dan yang dipimpin'. Peran FNKSDAadalah mendorong 'identitas kelas' melalui relasi hegemoni yang dibangunnya. 'Peran pemimpin' jika dalam FNKSDA disebut 'koordinator nasional' krusial untuk terus berperan menguatkan hubungan dengan komite di daerah-daerah. Serta perlu memiliki pengetahuan luas atas kondisi 'kelas' yang nyata di akar rumput.

Selain itu, suatu gerakan ekologi mengira akan stagnan mengusung identitasnya (Laclau \& Mouffe 1985). Padahal identitas tercipta dari proses konstruksi diskursif. Identitas dapat dimodifikasi melalui ekuivalensi di mana formasi hegemoni dibangun. Sehingga sosiabilitas gerakan demi memperluas 'aliansi', bukan hanya digunakan sekadar menjalin 'relasi'. Melampauinya, jika berani lebih radikal ialah memodifikasi identitas dari kekuatan yang terlibat dalam aliansi. Sehingga perjuangan nahdliyyin melawan antagon berupa kapitalisme, tidak terlepas dari perjuangan progresif lain yang berbeda.

\section{E. Kesimpulan}

Kasus-kasus perampasan ruang hidup, ketimpangan kepemilikan SDA, dalam bingkai lebih besarnya yakni kapitalisme maju khususnya kapitalisme ekstraktif telah menimpa nahdliyyin di berbagai daerah. Hal tersebut disikapi kaum muda nahdliyyin yang ternyata telah mengalami perkembangan, tidak hanya melayangkan kritik 
pada pemerintah khususnya Orde Baru saat itu. Namun telah menginisiasi terbangunnya gerakan FNKSDA pada 2013. Diusungnya isu kedaulatan SDA menunjukkan perluasan masalah agraria tidak hanya terkait lahan dan pertanian yang diatasi NU pada masa Era Sukarno dengan membentuk Pertanuyang bergerak melalui struktural NU dan memiliki banyak cabang.

NU saat ini telah memiliki arah gerak politik berbeda, bukan lagi organisasi politik namun organisasi kemasyarakatan. Kaum muda NUyang telah mengalami perkembangan pemikiran juga berimbas pada 'keragaman' isu yang digeluti oleh kaum muda nahdliyyin saat ini. Oleh karena itu, kemunculan gerakan FNKSDA merupakan satu historis baru dalam tubuh NU. Meskipun berjuang melalui non-struktural, namun menunjukkan watak politik progresif NU melalui 'budaya dan identitas baru politiknya'. FNKSDA tidak berjuang melalui NU sebagai 'partai politik' melainkan 'meradikalisasi demokrasi'. FNKSDA berada pada koridor perjuangan demokrasi bercorak popular sovereignty. Tujuannya ialah membebaskan nahdliyyin dan masyarakat lebih luas dari ketertindasan sistemik yang ditengarai antagon gerakan saat ini berupa kapitalisme maju khususnya kapitalisme ekstraktif. FNKSDA tampil sebagai gerakan identitas massa yang sifat perjuangannya hegemonik. Artinya tidak memimpin langsung 'kelas', namun menguatkan identitas kelas.

\section{Ucapan Terima Kasih}

Terima kasih penulis ucapkan kepada pihakpihak yang telah berkontribusi dalam riset dan penulisan artikel ini. Khususnya kepada kawankawan FNKSDA yang telah menjadi ruang belajar baru yang nyaman, menarik, dan menantang bagi penulis.

\section{Daftar Pustaka}

Affiat, RA 2019, 'Pilpres 2019, konsolidasi, dan rekonfigurasi kelas kapitalis-Islam bergerak', diakses 21 April 2019, <https://islambergerak.com/2019/04/pilpres-2019-konsolidasidan-rekonfigurasi-kelas-kapitalis/>.
Alhafiz, K 2015, 'PBNU haramkan eksploitasi sumber daya alam di Indonesia', NU Online, diakses 23 Maret 2019, <http://www.nu.or.id/ post/read/59422/pbnu-haramkan-eksploitasisumber-daya-alam-di-indonesia>.

Alvarez, SE 2018, Cultures of politics/politics of cultures: revisioning Latin American social movements, Routledge.

Bisri, AM 2012, 'Dialektika pemikiran Islam kontemporer', Akademika, vol. 6.

Burhani, AN 2016, Muhammadiyah berkemajuan: pergeseran dari puritanisme ke kosmopolitanisme, Mizan, Bandung.

Engineer, AA, Prihantoro, A, \& Ud, M 1999, Islam dan teologi pembebasan, Pustaka Pelajar, Yogyakarta.

Escobar, A \& Alvarez, SE 2018, The making of social movements in Latin America:identity, strategy, and democracy, Routledge.

FNKSDA 2013, Tentang kami, diakses 7 Maret 2019, $<$ https://daulathijau.wordpress.com/tentang$\mathrm{kami} />$.

FNKSDA 2018a, 'Pernyataan sikap front nahdliyyin untuk kedaulatan sumber daya alam Sumenep terhadap rencana kedatangan Sandiaga S. Uno di Sumenep, diakses 21 Maret 2019, <https://daulathijau.wordpress.com/2018/o9/ 27/pernyataan-sikap-front-nahdliyin-untukkedaulatan-sumber-daya-alam-sumenepterhadap-rencana-kedatangan-sandiaga-suno-di-sumenep/>.

FNKSDA 2018b, 'Aksi warga Silo Jember menolak pertambangan emas', diakses 23 Maret 2019, $<$ https://daulathijau.wordpress.com/2018/12/ 10/aksi-warga-silo-jember-menolakpertambangan-emas/>.

Hüsken, FAM 1998, Masyarakat desa dalam perubahan zaman: sejarah diferensiasi sosial di Jawa, 1830-1980, Gramedia Widiasarana Indonesia (Grasindo), Jakarta.

JATAM 2019, 'Oligarki tambang di balik pemilu 2019', diakses 26 Maret 2019, <http:// www.jatam.org/2019/o2/11/oligarki-tambangdi-balik-pemilu-2019/>.

Laclau, E \& Mouffe, C 1985, Hegemony and socialist strategy: towards a radical democratic poli- 
tics, Verso, London.

Lembar Kerja FNKSDA, F 2013, 'Lembar kerja FNKSDA'.

Luthfi, AN 2018, 'Sejarah dan revitalisasi perjuangan pertanian Nahdlatul Ulama melawan ketidakadilan agraria', BHUMI:Jurnal Agraria dan Pertanahan, vol. 3, no. 2, hlm. 145-159.

Maimunah, S 2019, Rezim ekstraksi, oligarki dan lubang tambang, diakses 26 Maret 2019, <http://www.jatam.org/2019/o3/20/rezimekstraksi-oligarki-dan-lubang-tambang/>.

Marx, K 2004, Kapital, sebuah kritik ekonomi politik, buku I:proses produksi kapitalis secara menyeluruh, Hasta Mitra, Jakarta.

Misrawi, Z 2002, 'Post tradisionalisme Islam: dari teologi teosentrisme menuju teologi antroposentrisme', Millah:Jurnal Studi Agama, UII, vol. 2, no. 1, hlm. 22-36.

Mouffe, C 200o, The democratic paradox, verso.

Mubarok, AFS 2016, Gerakan sosial lingkungan pemuda NU: studi pada front nahdliyyin untuk kedaulatan sumber daya alam (FNKSDA), Universitas Gadjah Mada.

Muhammad Al-Fayyadl 2015, Apa itu Islam progresif?s, diakses 17 Maret 2019, <https:// islambergerak.com/2015/o7/apa-itu-islamprogresif/>.

Murtadho, R 2015, Gus Dur dan Marxisme-Leninisme, diakses 23 Januari 2019, < <ttps:// indoprogress.com/2015/o9/gus-dur-danmarxisme-leninisme/>.

Mushoffa, I 2015, Apa yang progresif dari Islam progresif?, diakses 20 Maret 2019, <https:// islambergerak.com/2017/o6/apa-yangprogresif-dari-islam-progresif/>.
Nashirulhaq, M 2017, 'Perjuangan ekonomi-politik generasi muda Nahdlatul Ulama (NU): Studi atas Front Nahdliyyin untuk Kedaulatan Sumber Daya Alam (FNKSDA)', Skripsi pada Fakultas Ilmu Sosial dan Ilmu Politik UIN Syarif Hidayatullah.

NU 2019, 'NU Jember haramkan tambang emas Blok Silo, diakses 23 Maret 2019, <http:// www.nu.or.id/post/read/101299/nu-jemberharamkan-tambang-emas-blok-silo>.

PBNU 2015, 'Hasil-hasil muktamar ke-33 NU'.

PBNU 2017, 'Hasil musyawarah nasional alim ulama konferensi besar NU 2017'.

Tebuireng Online 2013a, Resolusi Jihad jilid II, diakses 8 Maret 2019, < h t t p s : / / tebuireng.online/resolusi-jihad-jilid-ii/>.

Tebuireng Online 2013b, Halaqah FNKSDA jihad melawan kapitalisme ekstraktif, viewed 5 Maret 2019, <https://tebuireng.online/ halaqah-fnksda-jihad-melawan-kapitalismeekstraktif/>.

Torfing, J 1999, New theories of discourse, Blackwell Publishers, Oxford.

Widayanti, S 2012, "Pemberdayaan masyarakat: pendekatan teoritis," Welfare Jurnal Ilmu Kesejahteraan Sosial, vol. 1, no. 1.

Zuhro, A.Z; Hakim, R 2019, 'Perjuangan berhasil, kementerian ESDM harus cabut keputusan wilayah izin tambang Blok Silo', diakses 23 Maret 2019, $\quad<$ h t t p s : / / www.mongabay.co.id/2019/o1/11/perjuanganberhasil-kementerian-esdm-harus-cabutkeputusan-wilayah-izin-tambang-blok-silo/>. 